\title{
A LOBBYIST'S DILEMMA ${ }^{1}$
}

Like he had done for the past 40 years, lobbyist James E. (Jet) Toney stepped into the cool, noisy marble halls under the Georgia Capitol Gold Dome. It was the morning of March $12^{\text {th }}, 2020$ the $28^{\text {th }}$ day of the Regular Session of the Georgia General Assembly. The $28^{\text {th }}$ day, traditionally called "crossover" day, was the last day for bills to move from one legislative body into the other for passage by the $40^{\text {th }}$ and final day of the Session (Exhibit 1). The talk under the Gold Dome that morning was less of legislation and more about the impending actions by Governor Brian Kemp to respond to the COVID-19 pandemic. Not two weeks prior the virus had claimed its first victim on U.S. shores. Speculation about the Governor's actions was rampant and contradictory, yet everyone agreed there would be disruptions.

Jet was the lobbyist for Georgia-based private, not-for-profit, colleges and universities, the Georgia Independent College Association (GICA). It was one of his oldest clients and each year during legislative sessions he was dedicated to representing their needs. 2020 was no different. That day Jet monitored the state budget actions on the Tuition Equalization Grant (TEG) and was keeping an eye on House Bill (HB) 840 (Exhibits 2 and 3). The bill was a potential problem for GICA and even though the bill was not yet on the House Calendar for debate Supplemental House Calendars could still be issued from the formidable Rules Committee (Exhibit 4).

While Jet watched and waited, the Governor and House and Senate leadership made an unprecedented decision. All legislators, support staffs, and others frequenting the Capitol halls and buildings would be sent home and could not return until they were told they could do so. The legislature could be called back into Session at any time during the rest of 2020 to complete the remaining 11 legislative days (Exhibit 5). As far as Jet or anyone recalled this had never happened before, not even in war time.

By the end of the day HB 840 appeared to be dead but as Jet knew it could easily be revived during the remaining 11 days. All it took was an alert legislator who knew the House or Senate Rules cold, and before any other busy or fatigued legislator or lobbyist noticed, floor procedures could revive the dead bill. Further it could take weeks or months to find the changes and by then the Governor might have signed the bill into law never giving interested parties a chance to argue for his veto.

Jet was left with a tough decision. How could he effectively communicate GICA's needs and keep HB 840 from being revived or attached to other legislation when all 180 House Members and all 56 Senators were scattered throughout the state and no longer located in one convenient place?

\footnotetext{
${ }^{1}$ Copyright $($ 2021, Mary Hodges West. This case was prepared for the purpose of class discussion, and not to illustrate the effective or ineffective handling of an administrative situation. Names and some information have been disguised. This case is published under a Creative Commons BY-NC license. Permission is granted to copy and distribute this case for non-commercial purposes, in both printed and electronic formats.
} 


\section{COVID-19}

According to the Centers for Disease Control and Prevention (CDC) in the United States, COVID-19 was "an outbreak of respiratory illness caused by a novel (new) coronavirus first identified in Wuhan, Hubei Province, China. Cases of COVID-19 also are being reported in a growing number of countries internationally, including the United States." (Centers for Disease Control and Prevention (CDC), 2020)

\section{About Coronaviruses}

The CDC website said that coronaviruses were named for the spikes on their surfaces that resemble a crown. First identified in the 1960s, human-infecting coronaviruses were: 229E, NL63, OC43, HKU1, MERS-CoV, SARS-CoV, and SARS-CoV-2 (now known as COVID-19). The most common that affected humans around the globe were 229E, NL63, OC43, HKU1. If an animal were infected with a coronavirus the virus could evolve to infect humans as well becoming a new human coronavirus. (CDC, 2020)

\section{Why Was COVID-19 a Big Problem?}

COVID-19 had been described as highly infectious spreading rapidly. It had a 14 day or longer incubation period which created a longer time frame during which infected people could widely spread the virus making it more difficult for international public health organizations to follow it from contact to contact. It could be highly lethal to less healthy and even seemingly healthy adult populations. Its symptoms were varied and unpredictable. For many months into the pandemic tests were not available or testing was limited. Medical facilities were overrun with patients and those that were not had no way of planning for potential or possible outbreaks.

Due to the high-level of unknowns government officials across the globe began to shut down schools, restrict access to government owned or run facilities, send workers home, and declare states of emergency. All these intended remedies were implemented as rapidly as possible leading to major, across-the-board disruptions. In the United States a series of occurrences which led up to March 12th, 2020, the date of this case, were:

- January 21 - first confirmed case in the United States.

- January 29 - two U.S. Pacific territories declared states of emergency.

- January 30 - World Health Organization declared global health emergency.

- January 31 - U.S. President restricted travel from China to the U.S.

- February 21 - first local U.S. transmission confirmed.

- February 29 - first U.S. death reported.

- $\quad$ March 12 - by end of day, 38 U.S. states and territories had declared states of emergency.

\section{Lobbying}

In the $21^{\text {st }}$ century the lobbying practice was a subset of Public Affairs known as Government Affairs. It was a form of persuasion used across time in many countries to influence policy changes at all types and levels of governments. The practice was used as much by individuals as by organizations to obtain 
favorable conditions in any area where policy was made. Some of these policy areas were taxation, business practice, budget funding, or property ownership.

\section{A History of Lobbying}

Lobbying had a long history even before the term entered common use in the $19^{\text {th }}$ century (MerriamWebster, 2017, "The Origins of 'Lobbyist"'). In ancient Rome elected officials and unelected aristocrats engaged in patron-client relationships known as clientelism. Clientelism was "a political or social system based on the relation of client to patron with the client giving political or financial support to a patron (as in the form of votes) in exchange for some special privilege or benefit (Clientelism (n.d.). In MerriamWebster.com dictionary)."

Roman clients were visited by their patrons almost daily. Clients were expected to show some form of 'respect' to their patrons who, in turn, funneled their clients' causes forward to the appropriate government body or official. Following the breakup of the Roman Empire and the expansion of monarchies across the former empire most monarchs extended the system of petitioning to their subjects. Petitioning was widely interpreted as an earlier form of lobbying (McKinley, 2018) and like the Roman client the petitioner made requests of the monarch, the monarch's department heads, and sometimes gave gifts as signs of respect and in hopes of future good will.

The split with Great Britain in the $18^{\text {th }}$ century left the new republic of the United States with an inadequate body of case law and very little codified law (Farnsworth, 2010). If citizens of the new country wanted to have their issues heard and influence laws and regulations, they needed to be where the legislators were. Elected officials and department heads in the federal and state governments met with citizens in their home districts taking advice, making policy decisions, and exchanging moneys before spending time in assemblies passing laws. Citizens also traveled to the legislatures to meet with government officials in the halls outside lawmaking chambers had already been termed lobbyers or lobby members (Merriam-Webster, 2017, para. 6).

By the late 1800s states and the federal government had established Capitol buildings in major cities throughout the country where elected officials gathered for longer and longer periods of time. They were busy creating a growing body of codified and regulatory law. Those who needed to have access to legislators followed the legislating and that meant moving the business of influence to where the legislators were - at the Capitols. It was in the 1920 s that lobbying in the U.S., as known in the $21^{\text {st }}$ century, took shape (Byrd, 2006). And the modern U.S. style lobbying tradition had since spread across the globe.

Lobbying in the $21^{\text {st }}$ century bore some resemblance to lobbying through the ages. It required direct contact to the officials that lobbyists were trying to influence, otherwise it was difficult for any lobbyist to maintain some control over policy promises made by legislators prior to laws being voted on, regulations being proffered, or moneys placed in budgets.

\section{The Georgia General Assembly}

\section{The Beginnings}

The Georgia General Assembly was established in 1777 while Georgia was still at war with Great Britain. It began operation even before the U.S. Congress and carried on without interruption since. From its inception until 1789 the assembly was a unicameral legislative body; it then became bicameral consisting of a House of Representatives and a Senate. The terms of office for the legislators in both bodies was two years. Each term of office consisted of a minimum of two regular sessions to be completed within a year. 
The Georgia state capital, the legislature, and the state's agencies settled in Atlanta in 1868. In 1889 after the devastation of the Civil War an impressive Capitol Building of marble and limestone festooned with a dome covered in sheets of hammered Dahlonega gold became the meeting place for the General Assembly and some state departments. Over time the area surrounding the Capitol grew into a sprawling government complex. The state bureaucracy grew so large it moved major offices to locations throughout the state.

Even the General Assembly grew. The Capitol structure housed mainly the General Assembly chambers, some related operations and offices for the legislative leadership, and the offices of three of the state's constitutional officers: Governor, Lieutenant Governor, and Secretary of State. Members of the General Assembly had their offices in a newer complex to the southwest of the Capitol building. All legislators had the option to also operate an office in their home districts.

The Georgia House of Representatives consisted of 180 members and the Senate had 56 members. The Representatives and Senators were elected to serve two-year terms of office. The House was presided over by the Speaker of the House. The Speaker came from among the 180 members of the House and was elected at the beginning of each new two-year term by the assembled members. The Senate was presided over by the President of the Senate. The President of the Senate was also the Lieutenant Governor. The Lieutenant Governor and the Governor both served four-year terms of office.

\section{The Legislative Sessions}

By constitutional requirement (Exhibit 6) the Regular Session (Session) of the General Assembly began each year on the second Monday in January and lasted for 40 legislative days. The 40 days did not need to be contiguous or continuous but had to follow a set of Rules (Exhibit 7) set down by each body for the conduct of its proceedings.

The General Assembly Sessions' purpose were to conduct official state business by modifying, creating, passing, or defeating current or new laws. Bills and resolutions were introduced by legislators, those bills and resolutions were assigned to committees by the presiding officers of the House or Senate. In some cases, the bills and resolutions made their way through both the House and Senate then on to the Governor's desk for signature or a veto. Most died along the way for several reasons, some of which were inattention to the process, disapproval by one or many individuals or groups, unpopularity, technical flaws, and not enough time left in the process.

Each year thousands of bills and resolutions were introduced during the Session and each year a few hundred were passed and signed by the Governor. Except for proposed constitutional amendments resolutions were usually introduced as feel-good measures, congratulating a constituent on an important personal event, or establishing a special day for a person or group. Bills however were the meat and potatoes of law and policy making and with the growth of codified law came the need for all kinds of people, businesses, and organizations to keep a close watch on laws and policies that could and would affect their interests. As a result of this volume in policy and law more and more of these individuals, organizations and businesses turned to lobbyists to help monitor legislation and defend their interests. As of this case, 1065 individuals were registered with the State of Georgia to operate as lobbyists (Georgia Government Transparency and Campaign Finance Commission (GGTCFC), 2020).

\section{The Lobbyist}

James E. (Jet) Toney was the Founder and Principal at Cornerstone Communications Group (Exhibit 8). After serving as director of the Georgia House of Representatives Public Information and 
Communications office in the 1980s Jet was a veteran governmental affairs consultant (aka lobbyist) of 45 regular and special sessions of the Georgia General Assembly. Since 2011 he had also been the Chair of the Georgia Professional Lobbyists Association (GPLA) which was one of at least 17 such associations countrywide and had a large membership. Through his affiliation with GPLA Jet was known as a lobbyist's lobbyist.

Since 1991 Jet and his business associate, Michael R. Holiman, parlayed their vast knowledge of public relations practices and legislative knowledge into a successful public affairs business. Cornerstone Communications Group represented at the local and state government levels an array of clients from nonprofits to government agencies to Fortune 500 companies. They also provided to their clients government affairs services, messaging, association management, and crisis communication. The nineperson Cornerstone team stayed busy throughout the year.

\section{The Client}

The Georgia Independent College Association (GICA) was an association of Georgia's private (independent), not-for-profit colleges and universities listed in Exhibit 9. On its website it stated its mission as follows:

Through partnerships with institutions, businesses, and community leaders, GICA supports private higher education in the areas of public policy, research, fundraising for student financial aid, and collaborative programs. GICA's 24 members serve more than 72,000 students. We are dedicated to educating tomorrow's leaders and meeting our State's current and future workforce needs (Georgia Independent College Association (GICA), 2018).

GICA’s tag line was Private Colleges Public Good (GICA, 2018).

Each year the GICA Board Chair and GICA President published the association Annual Report and Letter letting the public, contributors, students, legislators, and all those who lend to the financial health of the member colleges and universities know how the association and the schools performed during the previous year (Exhibit 10).

Students who attended and graduated from GICA member institutions attended some of the country's finest, historic black, women's, men's, Methodist, Baptist, Presbyterian, and agricultural private colleges and universities. These institutions provided students with focused, smaller, post-secondary liberal arts educations. These institutions had more flexibility to meet the needs of the regionally, ethnically, and religiously diverse urban and rural populations throughout the state of Georgia.

A large majority of the students who attend GICA colleges and universities did not have the financial options available to students who attend public post-secondary institutions. Private post-secondary institutions typically cost more and in 1972 the Georgia General Assembly created the Tuition Equalization Grant to begin in budget year 1973 (Georgia Student Finance Commission (GSFC), 2019). The Grant was available to only select private institutions shown in Exhibit 11.

\section{Tuition Equalization Grant}

The Tuition Equalization Grant was enacted in the 1970s by the Georgia General Assembly to help provide a better opportunity for Georgia students to attend Georgia private colleges and universities. These non-government owned and operated institutions, eligible to have their students receive the TEG, were scattered throughout the state. Some institutions provided smaller campus populations and class sizes. Others provided culture or religious-focused education. And others directed their educational attention on students with specific educational needs. These institutions were unsubsidized by tax 
revenues and the legislature wanted to give the diversity of urban, suburban, and rural students a chance to achieve a better affordable post-secondary education.

"Recipients receive an award of $\$ 317$ per quarter or $\$ 475$ per semester and can receive payment for up to four quarters or three semesters per year. (Budgeted each year by the Georgia Legislature. The amount of the award may change during the award year.)" (GSFC, 2020). As explained in the quote from the Georgia Student Finance Commission every time the General Assembly considered the budget the possibility of the TEG award increasing or decreasing was a reality.

\section{Countdown to What?}

The 2020 Regular Session of the Georgia General Assembly had been suspended, and Jet was back in his offices at Cornerstone Communications Group. He pondered his choices.

Using the usual, familiar communications options,

- $\quad$ Phone - each House and Senate Member had multiple fixed and mobile phone numbers.

- Email - each House and Senate Member had multiple personal, legislative, and business email addresses.

- Text - few legislators shared their mobile or mobile app text options with lobbyists, but those who did were easy to reach.

- Postal mail - each Member had multiple home, business, and legislative mailing addresses.

with no knowledge as to when the Session would be called back Jet could,

1. Contact by one or more methods all 236 House Members and Senators to pitch his client's positions on the TEG and the language in HB 840.

2. Contact by one or more methods the 86 House and 36 Senate Appropriations Committees members to secure commitments for his client's positions: or

3. Wait until the General Assembly is back in Session and pick up where he left off.

Jet folded his arms across his chest and sat back in his chair. Were these the only communication choices he had to get his client's needs across to the legislators? How would he know they received the message? How could he gauge message penetration and stickiness? Was this just a communications problem or something more? Lobbying had always been a tough business, but COVID-19 and the indeterminate nature of the Session suspension made it a whole lot tougher. 


\section{References}

Coronavirus Disease 2019 (COVID-19). (2020, June 20). Retrieved from

https://www.cdc.gov/media/dpk/diseases-and-conditions/coronavirus/coronavirus-2020.html

Human Coronavirus Types. (2020, June 20). Retrieved from https://www.cdc.gov/coronavirus/types.html

The Origins of 'Lobbyist'. (2017, October 18). Retrieved from https://www.merriam-webster.com/wordsat-play/the-origins-of-lobbyist

Clienteltism (n.d.). In Merriam-Webster.com dictionary. Retrieved from https://www.merriamwebster.com/dictionary/clientelism

McKinley, M. (2018). Petitioning and the Making of the Administrative State. Yale Law Journal, 127(6), 1538-1637. https://doi-org.ezproxy.lib.usf.edu/http://www.yalelawjournal.org/issue

Farnsworth, E. Allan. (2010). An Introduction to the Legal System of the United States. New York:

Oxford University Press, Inc.

Byrd, R. C. (2006). History of Lobbying. Congressional Digest, 85(5), 130.

Summary of Lobbyist Disclosures. (2020, September 13). Retrieved from https://media.ethics.ga.gov/search/Lobbyist/Lobbyist_ByName.aspx

Association Mission. (2018, August 29). Retrived from https://georgiacolleges.org/page/Misson

Tuition Equalization Grant Program, REGULATIONS - 600., 2016 - 2017 Award Year. (2019, June 13). Retrieved from https://gsfc.georgia.gov/sites/gsfc.georgia.gov/files/2017-TEG.pdf

Award Amount for the Tuition Equalization Grant Program. (2020). Retreived from https://www.gafutures.org/hope-state-aid-programs/scholarships-grants/georgia-tuition-equalizationgrant/award-amount

\section{Acknowledgements}

This case study was based on interviews with Georgia lobbyist James E. (Jet) Toney.

\section{Biography}

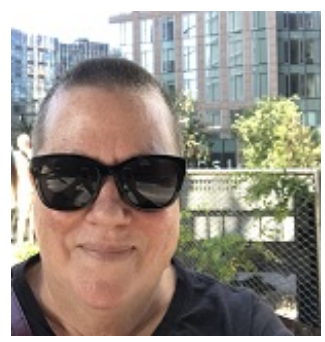

Mary Hodges West was a student in the Doctor of Business Administration program at the Muma College of Business, University of South Florida. Her undergraduate degree was in History with a concentration in Asia affairs. Mary was a former enlisted soldier and officer in the Georgia Army National Guard and Member of the Georgia House of Representatives and Georgia Senate. She was an olive grower, lobbyist, and writer. 


\section{How a Bill is Passed in the Georgia Legislature}

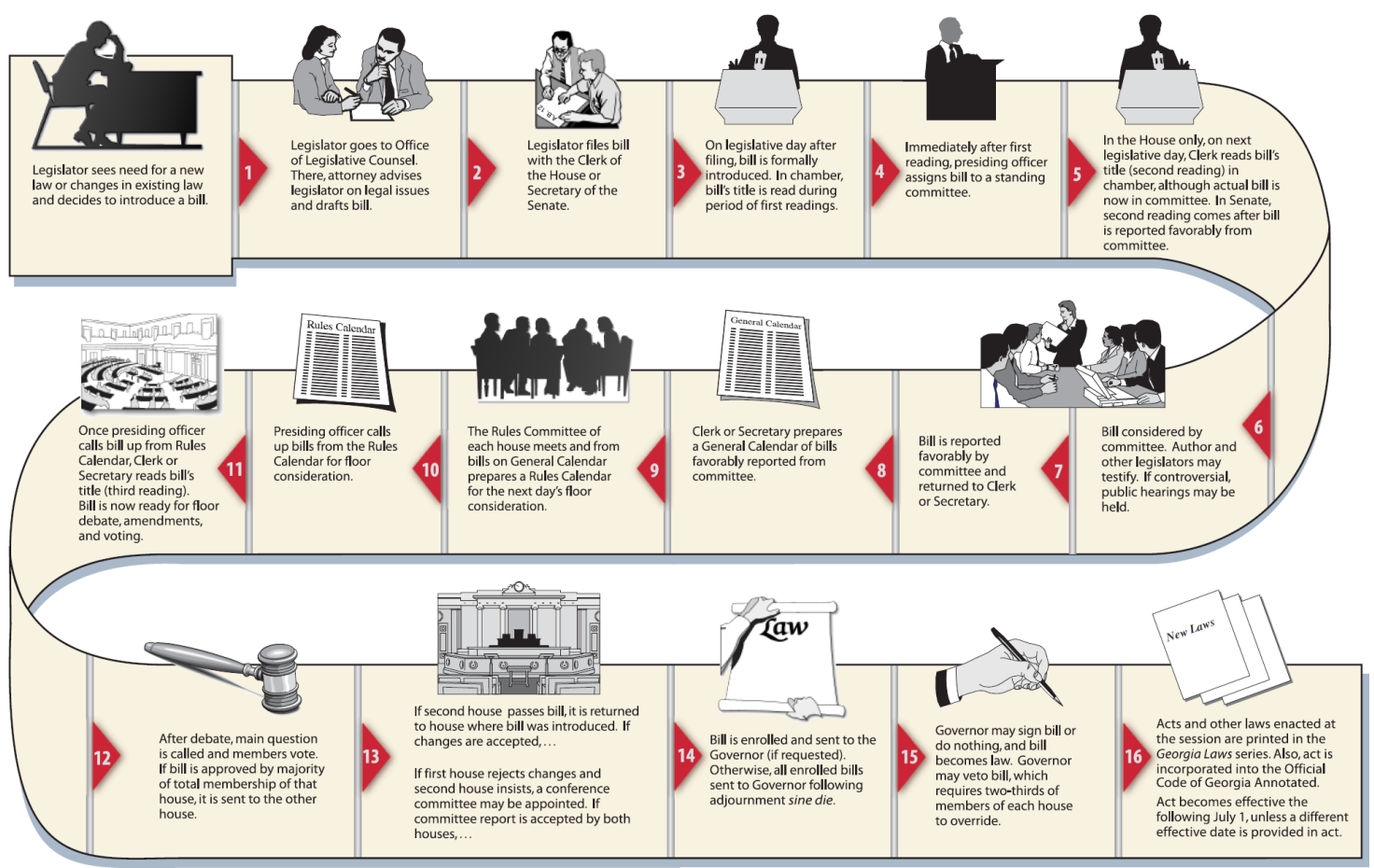

2007 Carl Vinson Institute of Government University of Georgia

Source: Carl Vinson Institute of Government University of Georgia. (2007). How a Bill is Passed in the Georgia Legislature. https://georgiainfo.galileo.usg.edu/documents/legchart.pdf 


\section{Exhibit 2: HB 840, Original Version}

House Bill 840

By: Representatives Wiedower of the $119^{\text {th }}$, Gaines of the $117^{\text {th }}$, Kelley of the $16^{\text {th }}$, Sainz of the $180^{\text {th }}$, and Jones of the $47^{\text {th }}$

\section{A BILL TO BE ENTITLED}

AN ACT

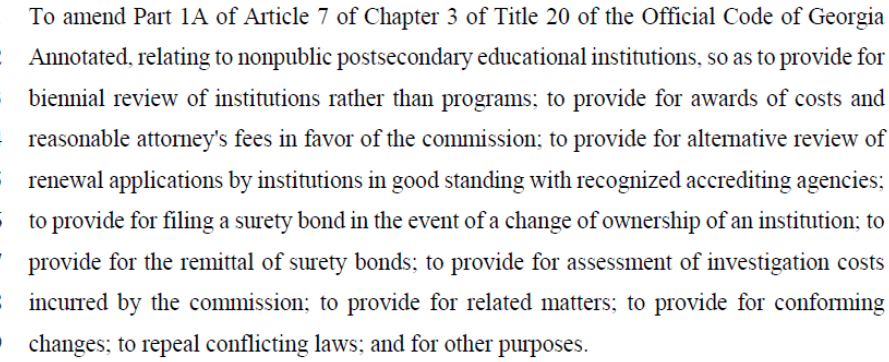

\section{SECTION 1.}

Part 1A of Article 7 of Chapter 3 of Title 20 of the Official Code of Georgia Annotated, relating to nonpublic postsecondary educational institutions, is amended in Code Section 20-3-250.5, relating to administration and general powers and duties, by revising subsection (e) as follows:

"(e) The commission shall be authorized to provide for biennial review of a previously authorized program of instruetion at any institution which has received accreditation by a national or regional an accrediting agency recognized by the United States Department of Education. The commission shall promulgate guidelines which shall be followed by the executive director in recommending such biennial program institutional reviews to the commission."

SECTION 2.

23 Said part is further amended in Code Section 20-3-250.6, relating to minimum standards for

24 educational institutions, by revising subsection (c) as follows:

H. B. 840

- 1 - 
"(c) Institutions otherwise exempt from certain provisions of this part under paragraphs (7), (10), (11), (12), and (14) (13) of subsection (a) of Code Section 20-3-250.3 shall be required to meet the standards of financial soundness and being capable of fulfilling commitments to students as provided in subparagraph (a)(1)(H) of this Code section, and, because of such requirement, each such institution shall provide the commission with audited financial statements as performed by an independent certified public accountant and at such times as the commission shall require. The commission may impose a fee to be paid by such institutions to offset the cost of receiving and reviewing such audited financial statements. Institutions otherwise exempt from certain provisions of this part under subsection (c) of Code Section 20-3-250.3 shall be required to submit annual financial reports to the commission when applying for annual renewal of exemption or authorization using the reporting format provided by the commission. In addition thereto, institutions otherwise exempt from certain provisions of this part under paragraph (10) of subsection (a) of Code Section 20-3-250.3 shall be subject to the requirements of Code Sections 20-3-250.8, 20-3-250.10, and 20-3-250.27. The reports to the Governor and to the General Assembly required by subsection (h) of Code Section 20-3-250.27 shall include a summary of the commission's findings from its review of audited financial statements required by this subsection."

\section{SECTION 3.}

Said part is further amended in Code Section 20-3-250.8, relating to application to operate or conduct postsecondary activities, by revising subsection (g) as follows:

"(g) At least 60 days prior to the expiration of an authorization to operate, the institution shall complete and file with the executive director an application form for renewal of its authorization to operate. Such renewal application shall be reviewed and acted upon as provided in subsections (c) through (f) of this Code section: provided. however, that alternative methods deemed adequate and appropriate by the executive director may be used to review renewal applications by nonpublic postsecondary educational institutions that are accredited by and in good standing with an accrediting agency recognized by the United States Department of Education.

Said part is further amended in Code Section 20-3-250.10, relating to surety bonds, filing, amount, release of surety, and suspension upon release of surety, by revising subsections (a) and (b) as follows:

"(a) At the time an initial application or applieation for a braneh faeility is made for authorization to operate or in the event of a change of ownership as provided for in

H. B. 840

-2 - 
MUMA CASE REVIEW

subsection ( $\mathrm{f}$ ) of Code Section 20-3-250.8, the executive director shall require the nonpublic postsecondary educational institution making such application to file with the executive director a good and sufficient surety bond in such sum as determined by subsection (b) of this Code section. Such bond shall be executed by the applicant as principal and by a surety company qualified and authorized to do business in this state. The bond shall be conditioned to provide indemnification to the Tuition Guaranty Trust Fund established in Code Section 20-3-250.27 and to any student or enrollee or that person's parent or guardian or class thereof determined to have suffered loss or damage as a result of any act or practice which is a violation of this part or of rules and regulations promulgated pursuant thereto by such nonpublic postsecondary educational institution and that the bonding company shall pay any final, nonappealable judgment rendered by the commission or any court of this state having jurisdiction, upon receipt of written notification thereof. If a bond is in force at the time of an institutional closure, the surety shall be required to remit the full face value of the bond. Regardless of the number of years that such bond is in force, the aggregate liability of the surety thereon shall in no event exceed the penal sum of the bond. The bond may be continuous.

(b) The minimum amount of the bond required by subsection (a) of this Code section shall be based on the gross tuition of the nonpublic postsecondary educational institution during the previous year or on the estimated gross tuition for the current year, whichever is larger, and shall be as follows:

\begin{tabular}{|c|c|}
\hline Gross Tuition & Minimum Bond \\
\hline $0.00-\$ 50,000.00$ & $\$ 20,000.00$ \\
\hline $50,001.00-100,000.00$ & $30,000.00$ \\
\hline $100,001.00-200,000.00$ & $50,000.00$ \\
\hline $200,001.00-300,000.00$ & $75,000.00$ \\
\hline $300,001.00-400,000.00$ & $100,000.00$ \\
\hline $400,001.00-500,000.00$ & $150,000.00$ \\
\hline $500,001.00$ and over $=1.000 .000 .00$ & $200,000.00$ \\
\hline 1.000 .001 .00 and over & $\underline{450.000 .00}$ \\
\hline
\end{tabular}

For situations where a nonpublic postsecondary educational institution is unable to secure a bond amount provided for by this subsection, a bank standby letter of credit secured from a federally insured financial institution shall be accepted pursuant to rules and regulations of the commission. Institutions with $\$ 1.000 .001 .01$ or more in the previous year's gross tuition or estimated gross tuition. whichever is larger, that are authorized and bonded prior to July 1.2020 . shall not be subject to the $\$ 450.000 .00$ bonding requirement unless a change of ownership occurs after July 1,2020."

\section{H. B. 840}


109 All laws and parts of laws in conflict with this Act are repealed.

\section{SECTION 5.}

aid part is further amended in Code Section 20-3-250.18, relating to initiation of court proceedings by executive director, by adding two new subsections to read as follows: "(c) In any complaint or action brought against a responding party by or on behalf of the commission in any court of competent jurisdiction to enforce the provisions of this part. where the court determines the responding party acted without substantial justification in not complying with the provisions of this part. the court shall. unless it finds that special circumstances exist. assess in favor of the commission reasonable attorney's fees and other litigation costs reasonably incurred.

(d) The executive director shall have the ability to assess reasonable investigation costs incurred by the commission against any person. agent. group. or entity found to have violated any provision of this part."

\section{SECTION 6.}

Source: Georgia Legislature website link http://www.legis.ga.gov/Legislation/20192020/188778.pdf. 


\title{
Exhibit 3: HB 840, Substituted Version
}

The House Committee on Higher Education offers the following substitute to HB 840:

\author{
A BILL TO BE ENTITLED \\ AN ACT \\ To amend Part 1A of Article 7 of Chapter 3 of Title 20 of the Official Code of Georgia \\ Annotated, relating to nonpublic postsecondary educational institutions, so as to provide for \\ biennial review of institutions rather than programs; to provide for awards of costs and \\ reasonable attomey's fees in favor of the commission; to provide for alternative review of \\ renewal applications by institutions in good standing with recognized accrediting agencies: \\ to provide for filing a surety bond in the event of a change of ownership of an institution; to \\ provide for the remittal of surety bonds; to provide for assessment of investigation costs \\ incurred by the commission; to provide for a definition; to provide for related matters; to \\ provide for conforming changes; to repeal conflicting laws; and for other purposes. \\ BE IT ENACTED BY THE GENERAL ASSEMBLY OF GEORGIA:

\section{SECTION 1.} \\ Part 1A of Article 7 of Chapter 3 of Title 20 of the Official Code of Georgia Annotated, \\ relating to nonpublic postsecondary educational institutions, is amended in Code Section \\ 20-3-250.2, relating to definitions, by inserting a new paragraph to read as follows: \\ "(3.2) 'Branch facility' means any campus affiliated with an institution with a current \\ authorization to operate where instruction and administrative functions occur." \\ SECTION 2. \\ Said part is further amended in Code Section 20-3-250.5, relating to administration and \\ general powers and duties, by revising subsection (e) as follows: \\ "(e) The commission shall be authorized to provide for biennial review of a previously \\ authorized program of instrtetion at any institution which has received accreditation by a \\ national or regional an accrediting agency recognized by the United States Department of \\ Education. The commission shall promulgate guidelines which shall be followed by the \\ executive director in recommending such biennial program institutional reviews to the \\ commission."
}

H. B. 840 (SUB) 
SECTION 3.

27 Said part is further amended in Code Section 20-3-250.6, relating to minimum standards for

educational institutions, by revising subsection (c) as follows:

"(c) Institutions otherwise exempt from certain provisions of this part under paragraphs (7), (10), (11), (12), and (14) (13) of subsection (a) of Code Section 20-3-250.3 shall be required to meet the standards of financial soundness and being capable of fulfilling commitments to students as provided in subparagraph $(\mathrm{a})(1)(\mathrm{H})$ of this Code section, and, because of such requirement, each such institution shall provide the commission with audited financial statements as performed by an independent certified public accountant and at such times as the commission shall require. The commission may impose a fee to be paid by such institutions to offset the cost of receiving and reviewing such audited financial statements. Institutions otherwise exempt from certain provisions of this part under subsection (c) of Code Section 20-3-250.3 shall be required to submit annual financial reports to the commission when applying for annual renewal of exemption or authorization using the reporting format provided by the commission. In addition thereto, institutions otherwise exempt from certain provisions of this part under paragraph (10) of subsection (a) of Code Section 20-3-250.3 shall be subject to the requirements of Code Sections 20-3-250.8, 20-3-250.10, and 20-3-250.27. The reports to the Governor and to the General Assembly required by subsection (h) of Code Section 20-3-250.27 shall include a summary of the commission's findings from its review of audited financial statements required by this subsection."

\section{SECTION 4}

Said part is further amended in Code Section 20-3-250.8, relating to application to operate or conduct postsecondary activities, by revising subsection (g) as follows:

"(g) At least 60 days prior to the expiration of an authorization to operate, the institution shall complete and file with the executive director an application form for renewal of its authorization to operate. Such renewal application shall be reviewed and acted upon as provided in subsections (c) through (f) of this Code section; provided. however, that alternative methods deemed adequate and appropriate by the executive director may be used to review renewal applications by nonpublic postsecondary educational institutions that are accredited by and in good standing with an accrediting agency recognized by the United States Department of Education."

H. B. 840 (SUB) 


\section{SECTION 5}

Said part is further amended in Code Section 20-3-250.10, relating to surety bonds, filing, amount, release of surety, and suspension upon release of surety, by revising subsections (a) and (b) as follows:

"(a) At the time an initial application or application for a branch facility is made for authorization to operate or in the event of a change of ownership as provided for in subsection ( $f$ ) of Code Section 20-3-250.8, the executive director shall require the nonpublic postsecondary educational institution making such application to file with the executive director a good and sufficient surety bond in such sum as determined by subsection (b) of this Code section. Such bond shall be executed by the applicant as principal and by a surety company qualified and authorized to do business in this state. The bond shall be conditioned to provide indemnification to the Tuition Guaranty Trust Fund established in Code Section 20-3-250.27 and to any student or enrollee or that person's parent or guardian or class thereof determined to have suffered loss or damage as a result of any act or practice which is a violation of this part or of rules and regulations promulgated pursuant thereto by such nonpublic postsecondary educational institution and that the bonding company shall pay any final, nonappealable judgment rendered by the commission or any court of this state having jurisdiction, upon receipt of written notification thereof. If a bond is in force at the time of an institutional closure. the surety shall be required to remit the full face value of the bond. Regardless of the number of years that such bond is in force, the aggregate liability of the surety thereon shall in no event exceed the penal sum of the bond. The bond may be continuous.

(b) The minimum amount of the bond required by subsection (a) of this Code section shall be based on the gross tuition of the nonpublic postsecondary educational institution during the previous year or on the estimated gross tuition for the current year, whichever is larger, and shall be as follows:

\begin{tabular}{|c|c|}
\hline Gross Tuition & Minimum Bond \\
\hline $0.00-\$ 50,000.00$ & $\$ 20,000.00$ \\
\hline $50,001.00-100,000.00$ & $30,000.00$ \\
\hline $100,001.00-200,000.00$ & $50,000.00$ \\
\hline $200,001.00-300,000.00$ & $75,000.00$ \\
\hline $300,001.00-400,000.00$ & $100,000.00$ \\
\hline $400,001.00-500,000.00$ & $150,000.00$ \\
\hline $500,001.00$ and over $=1.000 .000 .00$ & $200,000.00$ \\
\hline$\underline{1.000 .001 .00-2.000 .000 .00 .}$. & $\underline{300.000 .00}$ \\
\hline
\end{tabular}

H. B. 840 (SUB)

-3 - 
For situations where a nonpublic postsecondary educational institution is unable to secure a bond amount provided for by this subsection, a bank standby letter of credit secured from a federally insured financial institution shall be accepted pursuant to rules and regulations of the commission. Institutions with $\$ 1,000,001.01$ or more in the previous year's gross tuition or estimated gross tuition. whichever is larger, that are authorized and bonded prior to July 1. 2020. shall not be subject to the $\$ 300.000 .00$ or the $\$ 450.000 .00$ bonding requirement unless a change of ownership occurs after July 1.2020."

\section{SECTION 6.}

102 Said part is further amended in Code Section 20-3-250.18, relating to initiation of court proceedings by executive director, by adding two new subsections to read as follows:

"(c)(1) In any legal or administrative action brought against a responding party by or on behalf of the commission in any court of competent jurisdiction to enforce the provisions of this part. where the court determines the responding party acted without substantial justification in not complying with the provisions of this part. the court shall. unless it finds that special circumstances exist. assess in favor of the commission reasonable attorney's fees and other litigation costs reasonably incurred.

(2) In any appeal hearing brought pursuant to Code Section 20-3-250.13 or 20-3-250.15 or paragraph (7) of subsection (g) of Code Section 20-3-250.27. where the court of competent jurisdiction determines that the petitioning party acted without substantial justification in pursuing such appeals hearing or in not complying with the provisions of this part, the court shall. unless it finds that special circumstances exist. assess in favor of the commission reasonable attorney's fees and other litigation costs reasonably incurred.

(d) The executive director shall have the ability to assess investigation costs not to exceed actual costs incurred by the commission against any person. agent. group, or entity found to have violated any provision of this part."

120

SECTION 7.

121 All laws and parts of laws in conflict with this Act are repealed.

H. B. 840 (SUB)

-4 -

Source: Georgia Legislature website link http://www.legis.ga.gov/Legislation/20192020/192701.pdf 


\title{
Exhibit 4: House Supplemental Rules Calendar
}

\author{
HOUSE SUPPLEMENTAL RULES CALENDAR
}

THURSDAY, MARCH 12, 2020

Mr. Speaker and Members of the House:

The Committee on Rules has fixed the calendar for this 28th Legislative Day as enumerated below:

DEBATE CALENDAR

Pursuant to House Rule 33.3. Debate shall be limited to no more than one hour on each piece of legislation. Time to be allocated at the discretion of the Speaker.

\section{Modified Open Rule}

HR 1163 Justice Robert Benham Bridge; Bartow County; dedicate (Substitute)(Trans-Gambill-15th)

HR 1216 Rappé Way; City of Savannah; rededicate (Trans-Gilliard-162nd)

$\underline{\text { HR } 1300}$ Glynn County; Murray County; change of use of certain property; authorize (SProp-Pirkle-155th)

\section{Modified Structured Rule}
HB 61 Motor vehicle insurance companies; offer qualified active duty military service members between the ages of 18 and 24 motor vehicle insurance policies underwritten at rates for such service members 25 years of age or older; require (Substitute)(Ins-Glanton-75th)
HB 86 Education; complaints policy for teachers and other school personnel; provisions (Substitute)(Ed-Benton-31st)
HB 336 Retirement and pensions; require certain public employers to make employer and employee contributions to the Teachers Retirement System of Georgia for beneficiaries employed by such certain public employers (Substitute)(Ret-Blackmon-146th)
HB 452 Revenue, Department of; access Bank Match Registry for certain purposes; allow (Substitute)(Judy-Sainz-180th)
HB 593 Tax Commissioners Retirement Fund of Georgia; create (Ret-Benton-31st)
HB 674 Alcoholic beverages; Department of Revenue to develop and implement a state-wide centralized application process for retailers for initial applications and renewals of license and permits; provide (RegI-Powell-32nd)
HB 690 Buildings and housing; agricultural structures from permitting fees; exempt (Substitute)(A\&CA-Burchett-176th)
HB 719 Crimes and offenses; modemization of HIV related laws; provide (Substitute)(H\&HS-Silcox-52nd)
(Rules Committee Substitute LC 33 8339S)
HB 736 Education; loan forgiveness program for teachers who agree to teach in a turnaround school in a high demand subject area; establish (Substitute)(HEd-Belton-112th)
HB 821 Retirement and pensions; granting postretirement benefit adjustments to certain individuals; provisions (Ret-Sainz-180th)
HB 840 Nonpublic postsecondary educational institutions; biennial review of institutions rather than programs; provide (Substitute) (HEd-Wiedower-119th)
HB 848 State government; provide the Department of Administrative Services additional options when disposing of surplus property in the best interest of the state; change certain definitions (GAff-Blackmon-146th)


HB 865 Wills, trusts, and administration of estates; Revised Probate Code of 1998; revise and update provisions (Substitute)(Judy-Scoggins-14th)

HB 886 Animals; veterinarians or veterinary technicians that provide treatment to animals to scan such animals' microchips and to report ownership information under certain circumstances; require (Substitute) (A\&CA-Welch-110th)

HB 912 Social services; authorize foster parents to arrange for short-term babysitting (JuvJ-Reeves-34th)

HB 927 Air quality; reporting of any unpermitted release of ethylene oxide to the Environmental Protection Division of the Department of Natural Resources: provide (Substitute)(NR\&E-Parsons-44th)

HB 953 Administrative Services, Department of; certain terms in particular types of state contracts shall be void and unenforceable and should not be included in such agreements; provide (GAff-Rich-97th)

HB 958 The Maternity Supportive Housing Act; enact (Substitute) (JuvJ-Setzler-35th)

HB 959 Solid waste management; surcharges imposed by local governments regarding municipal solid waste facilities operated by private enterprise; increase (Substitute)(NR\&E-Meeks-178th)

(Rules Committee Substitute LC 45 0481S)

HB 998 Game and fish; effective date of rules and regulations promulgated by the Board of Natural Resources: change (Substitute)(GF\&P-Rhodes-120th)

HB 1014 Local government; downtown development authorities; remove provision providing perpetual existence to such authorities (GAff-Tankersley-160th)

HB 1020 Motor vehicles; license suspension for conviction of drug related offenses; provide (Substitute)(MotV-Gravley-67th)

HB 1032 Health; certificate of need laws; provisions (Substitute) (SCQHC-Hatchett-150th)

$\underline{\text { HB } 1045}$ Insurance; include flood risk reduction in the enumerated list of county purposes for which certain proceeds from county taxes shall be used (Substitute)(GAff-Hogan-179th)

$\underline{\text { HB } 1050}$ Georgia Life and Health Insurance Guaranty Association; certain persons receiving insurance coverage from health maintenance organization subscriber contracts or health care corporation plans; extend association protections (Ins-Lumsden-12th)

HB 1057 Agriculture; further regulation of soil amendments derived from industrial by-products by local governments; authorize (Substitute) (A\&CA-Rhodes-120th)

HB 1073 Local government; creation of regional development authorities; provide (Substitute)(GAff-Watson-172nd)

HB 1090 Labor and industrial relations; provisions regarding employer's obligation to provide break time for an employee to express breast milk; revise (H\&HS-Silcox-52nd)

HB 1092 Professions and businesses; authorize delegation by a physician to an advanced practice registered nurse to order radiographic imaging tests in non-life threatening situations (Substitute)(RegI-Powell-32nd)

HB 1098 Highways, bridges, and ferries; development of a state-wide strategic transportation plan; provide (Trans-Carpenter-4th)

HB 1122 Regional commissions; appointment of nonpublic members to the councils; revise provisions (Substitute)(GAff-Watson-172nd) 
Structured Rule

HB 448 Excise tax; rooms, lodgings, and accommodations; revise definition of innkeeper to include lodging facilitators (Substitute)(W\&M-Dollar-45th) (Rules Committee Substitute LC 43 1625S)

HB 864 Excise tax; sale of vapor devices and consumable vapor products; provide (Substitute)(W\&M-Rich-97th)

HB 907 Military; additional time period of service in the definition of "war veteran"; include (D\&VA-Sainz-180th)

HB 1037 Georgia Entertainment Industry Investment Act; move certain sound recordings from qualified production activities to production expenditures (Substitute)(W\&M-Dollar-45th)

Bills and Resolutions on this calendar may be called in any order the Speaker desires.

Respectfully submitted,

SMITH OF THE 134th, CHAIRMAN

Source: Georgia Legislature website link

http://www.house.ga.gov/clerk/HouseCalendars/20192020/Supplemental-Rules-Calendar-3-122020.docx.pdf. 


\section{Exhibit 5: Signed Joint Session Suspension Order}

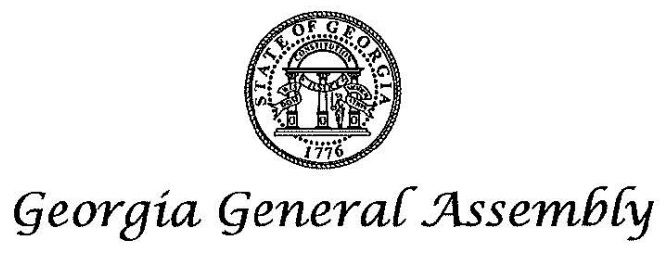

March 13, 2020

Dear Member of the General Assembly,

The Georgia General Assembly will suspend the 2020 legislative session indefinitely beginning today, Friday, March 13 , the end of the $29^{\text {th }}$ Legislative Day. This suspension is out of an abundance of caution and in the interest of the health and safety of members, staff and the public given the measures that need to be taken regarding the coronavirus.

House Resolution 1473 was adopted by both the House of Representatives and the Senate on March 12, 2020. The resolution provides

"that whenever, due to an emergency or disaster, resulting from manmade or natural causes or enemy attack, it becomes imprudent, inexpedient, or impossible to conduct the affairs of the General Assembly ....the Speaker of the House of Representatives and the President of the Senate may, by joint agreement, order the discontinuation of the schedule for meetings provided by this resolution and provide for reconvening the House and the Senate at the State Capitol in Atlanta, Fulton County, on such date and at such time as they deem practical."

As provided for in the resolution we will give prompt notice when we have jointly reached a determination as to when it is prudent for the General Assembly to reconvene. Following such reconvening, the General Assembly may provide by joint resolution for a new schedule for meetings and adjournments.

The adoption of this resolution by the General Assembly shall constitute the consent of both the House of Representatives and the Senate for purposes of Article III, Section IV, Paragraph I(b) of the Constitution.

"(b) Neither house shall adjourn during a regular session for more than three days or meet in any place other than the state capitol without the consent of the other." 
We continue to urge calm and appropriate responses to the coronavirus situation. We are working diligently to ensure that, at the appropriate time, the General Assembly resumes its critically important work.

We do not take this action lightly, but after discussions with Governor Kemp, we feel this is a prudent measure which will ensure an orderly legislative session. We stand ready to support the state's response to the coronavirus. We look forward to resuming the legislative session and returning to the pcople's business.
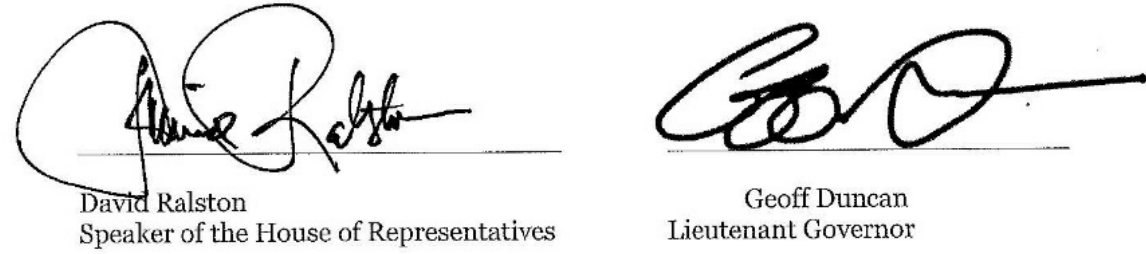

Geoff Duncan

Lieutenant Governor

Source: Georgia Legislature website link

http://www.senate.ga.gov/sos/Documents/Session_Suspension_Signed_Joint_Letter 3.13.2020.pdf 
Exhibit 6: Ga. Const. Art. III, § IV, Para. I

\author{
Lexis Advance ${ }^{\circledR}$ \\ Document: Ga. Const. Art. III, § IV, Para. I
}

Ga. Const. Art. III, § IV, Para. I

Copy Citation

Current through the 2019 Regular Session of the General Assembly and HB 276 and HB 444 of the 2020 Regular Session of the General Assembly

GA - Georgia Constitution CONSTITUTION OF THE STATE OF GEORGIA ARTICLE III. LEGISLATIVE

BRANCH SECTION IV. ORGANIZATION AND PROCEDURE OF THE GENERAL ASSEMBLY

PARAGRAPH I. Meeting, time limit, and adjournment

(a) The Senate and House of Representatives shall organize each odd-numbered year and shall be a different General Assembly for each two-year period. The General Assembly shall meet in regular session on the second Monday in January of each year, or otherwise as provided by law, and may continue in session for a period of no longer than 40 days in the aggregate each year. By concurrent resolution, the General Assembly may adjourn any regular session to such later date as it may fix for reconvening. Separate periods of adjournment may be fixed by one or more such concurrent resolutions.

(b) Neither house shall adjourn during a regular session for more than three days or meet in any place other than the state capitol without the consent of the other. Following the fifth day of a special session, either house may adjourn not more than twice for a period not to exceed seven days for each such adjournment. In the event either house, after the thirtieth day of any session, adopts a resolution to adjourn for a specified period of time and such resolution and any amendments thereto are not adopted by both houses by the end of the legislative day on which adjournment was called for in such resolution, the Governor may adjourn both houses for a period of time not to exceed ten days.

(c) If an impeachment trial is pending at the end of any session, the House shall adjourn and the Senate shall remain in session until such trial is completed.

OFFICIAL CODE OF GEORGIA ANNOTATED

Copyright 2020 by The State of Georgia

All rights reserved.

Content Type:

Terms:

Narrow By: -None-

Date and Time: May 16, 2020 07:03:08 p.m. EDT

Source: Georgia Legislature website link to Georgia Constitution. http://www.legis.ga.gov 


\section{RULES, ETHICS AND DECORUM}

OF THE

HOUSE OF REPRESENTATIVES

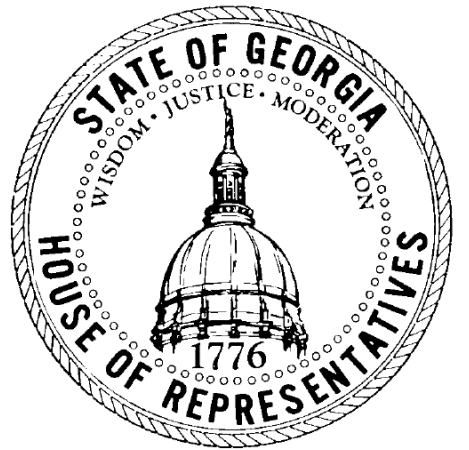

\section{9-2020} BIENNIUM

Adopted January 14, 2019 
TABLE OF CONTENTS

\section{RULES, ETHICS AND DECORUM OF THE HOUSE OF REPRESENTATIVES}

\begin{tabular}{|c|c|c|}
\hline & Rule \# & Begins on Page \\
\hline$\ldots \ldots \ldots \ldots \ldots \ldots \ldots \ldots$ & 1 & 1 \\
\hline \multicolumn{3}{|l|}{ Clerk, Doorkeeper, Messenger and } \\
\hline Sergeant-at-Arms . . . . . . . . . . . . . & $2-6$ & 2 \\
\hline \multicolumn{3}{|l|}{ Admission to the Chamber and Galleries and } \\
\hline Decorum Therein $\ldots \ldots \ldots \ldots \ldots \ldots \ldots$ & $7-9$ & 3 \\
\hline Committee Organization and Functioning . . . . . & $10-11$ & 6 \\
\hline Assignments, Appointments and Placements ... & $12-18$ & 10 \\
\hline Speaker's Powers and Duties. . . . . . . . . . & $19-29$ & 13 \\
\hline Protest and Appeal $\ldots \ldots \ldots \ldots \ldots \ldots \ldots$ & 30 & 15 \\
\hline General Business and Order of Business . . . . . & $31-44$ & 16 \\
\hline Quorum and Absentees . . . . . . . . . . . . & $45-47$ & 21 \\
\hline Introduction and Reading $\ldots \ldots \ldots \ldots \ldots \ldots$ & $48-53$ & 22 \\
\hline \multicolumn{3}{|l|}{ Consideration of Bills and Resolutions } \\
\hline in Committee $\ldots \ldots \ldots \ldots \ldots \ldots \ldots$ & $54-59$ & 24 \\
\hline Committee of the Whole House $\ldots \ldots \ldots \ldots \ldots$ & $60-78$ & 26 \\
\hline Debate $\ldots \ldots \ldots \ldots \ldots \ldots \ldots \ldots$ & $79-86$ & 30 \\
\hline Motions $\ldots \ldots \ldots \ldots \ldots \ldots \ldots \ldots$ & $87-89$ & 32 \\
\hline Commitment $\ldots \ldots \ldots \ldots \ldots \ldots \ldots \ldots$ & $90-92$ & 33 \\
\hline Tabling $\ldots \ldots \ldots \ldots \ldots \ldots \ldots \ldots \ldots$ & $93-98$ & 33 \\
\hline Indefinite Postponement $\ldots \ldots \ldots \ldots \ldots \ldots$ & $99-101$ & 34 \\
\hline Postponement $\ldots \ldots \ldots \ldots \ldots \ldots \ldots \ldots$ & $102-107$ & 35 \\
\hline Amendment $\ldots \ldots \ldots \ldots \ldots \ldots \ldots \ldots$ & $108-120$ & 36 \\
\hline Previous Question $\ldots \ldots \ldots \ldots \ldots \ldots \ldots \ldots$ & $121-127$ & 40 \\
\hline Voting $\ldots \ldots \ldots \ldots \ldots \ldots \ldots \ldots$ & $128-142$ & 42 \\
\hline Reconsideration $\ldots \ldots \ldots \ldots \ldots \ldots \ldots \ldots$ & $143-145$ & 46 \\
\hline Committees of Conference . . . . . . . . . . . & 146 & 47 \\
\hline Enactment $\ldots \ldots \ldots \ldots \ldots \ldots \ldots \ldots \ldots$ & $147-151$ & 48 \\
\hline Adjournment $\ldots \ldots \ldots \ldots \ldots \ldots \ldots \ldots$ & $152-158$ & 49 \\
\hline Contests $\ldots \ldots \ldots \ldots \ldots \ldots \ldots \ldots \ldots \ldots$ & 159 & 51 \\
\hline Pages $\ldots \ldots \ldots \ldots \ldots \ldots \ldots \ldots \ldots \ldots \ldots \ldots$ & 160 & 51 \\
\hline Privileged Resolutions. . . . . . . . . . . . . . & $161-162$ & 52 \\
\hline Legislative Offices $\ldots \ldots \ldots \ldots \ldots \ldots \ldots$ & 163 & 52 \\
\hline Ethics Committee $\ldots \ldots \ldots \ldots \ldots \ldots \ldots$ & $164-173$ & 52 \\
\hline Confidentiality of Certain Staff Services . . . . . & 174 & 62 \\
\hline
\end{tabular}

Source: Georgia State House website link http://www.house.ga.gov/Documents/Information/HouseRules2019.pdf. 


\section{RULES OF \\ The GeOrgia Senate}

2019-2020 TERM

ADOPTED: MARCH 29, 2019 


\section{RULES OF THE GEORgIA SENATE TABLE OF CONTENTS}

\section{SECTION ONE}

\section{OFFICERS, SENATORS, EMPLOYEES, AND ETHICS}

\begin{tabular}{|c|c|c|}
\hline $1-1.1$ & ...President of the Senate & Page 1 \\
\hline $1-1.2$ & ...President Pro Tempore & Page 2 \\
\hline $1-1.3$ & ...Voting Rights of a Senator When Presiding & Page 2 \\
\hline $1-1.4$ & 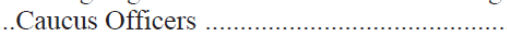 & Page 3 \\
\hline $1-1.5$ & ...Secretary of the Senate & Page 3 \\
\hline $1-1.6$ & ...Sergeant at Arms ........ & Page 3 \\
\hline
\end{tabular}

PART 2: SENATORS

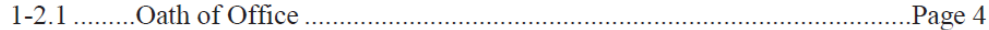

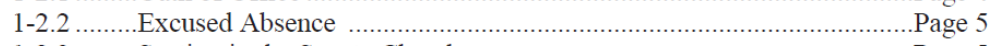

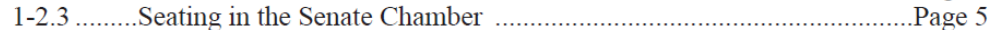

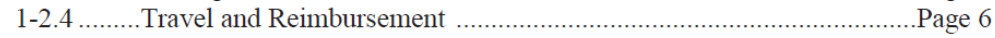

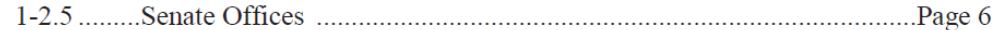

PART 3: EMPLOYEES OF THE SENATE

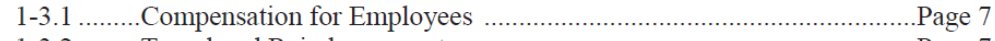

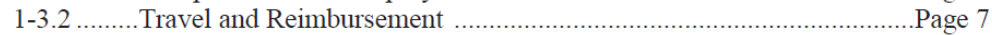

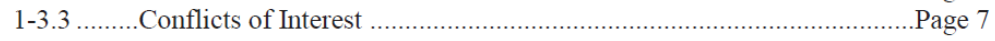

PART 4: CONDUCT AND ETHICS

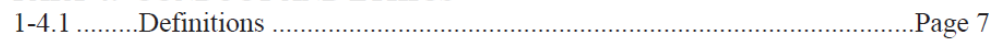

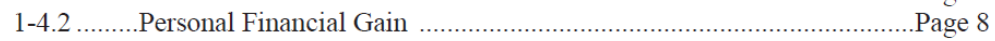

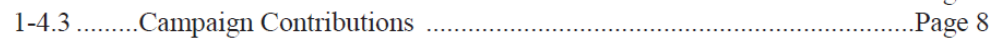

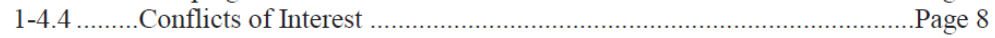

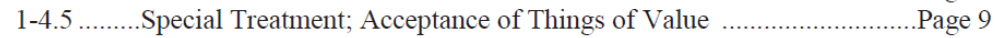

1-4.6 .........Crimes of Moral Turpitude and Controlled Substances ....................Page 9

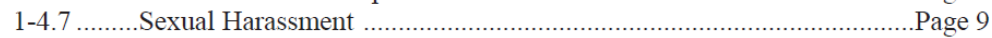

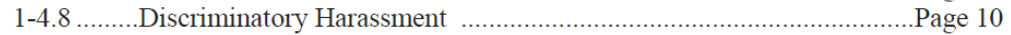

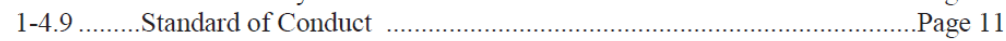

1-4.10 .......Committee on Ethics .....................................................................Page 11

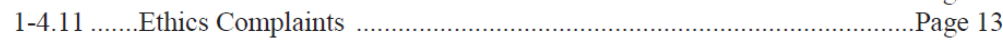

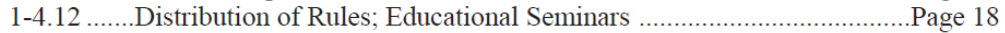

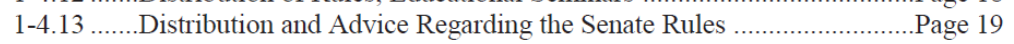


PART 5: PUBLIC MEETINGS

1-5.1 .......... Open Meetings; Closure under Certain Circumstances ......................Page 19

\section{SECTION TWO}

\section{COMMITTEES}

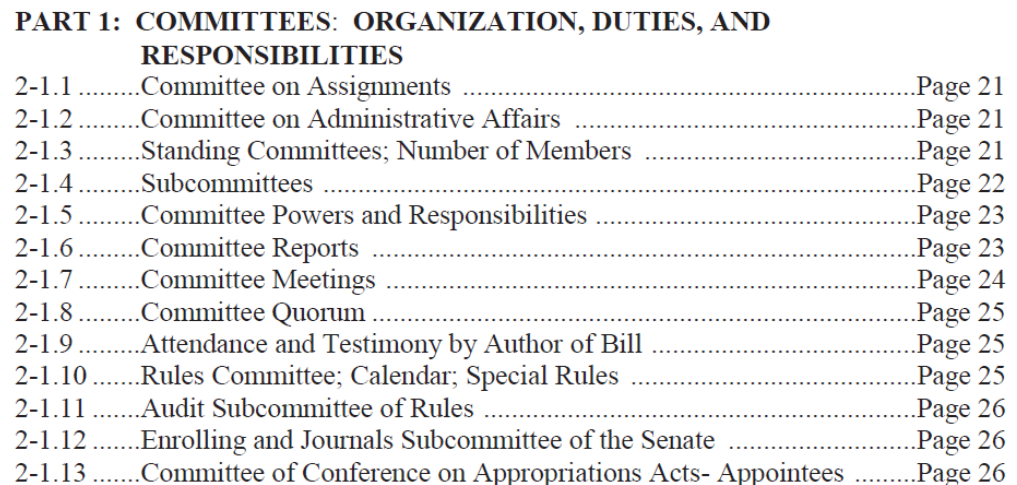

PART 2: COMMITTEE OFFICERS

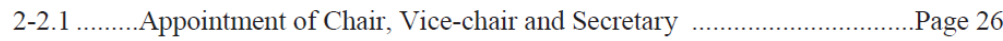

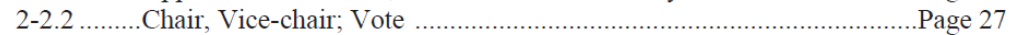

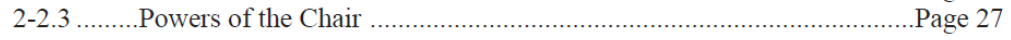

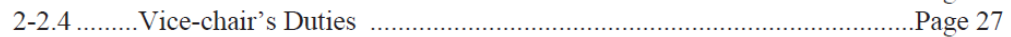

PART 3: COMMITTEE MEMBERS

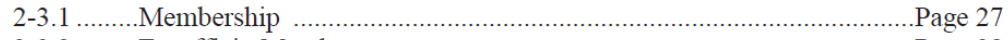

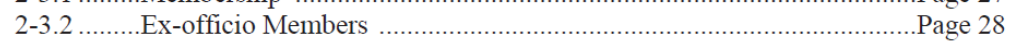

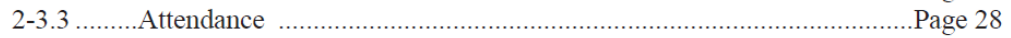

PART 4: COMMITTEE VOTING

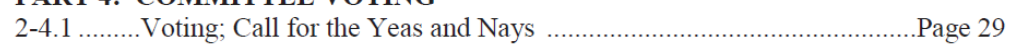

2-4.2 .........Voting in Committee; Duty to Vote; Exceptions ................................Page 29

PART 5: COMMITTEE MOTIONS AND PRECEDENCE

$2-5.1$..........Motions; How Made ....................................................................... 30

2-5.2 …......Motions; Do Pass; Do Not Pass; Effect .............................................Page 30

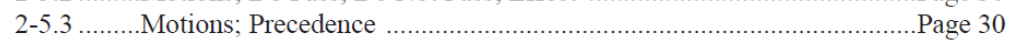


PART 6: COMMITTEE DECORUM AND DEBATE

2-6.1 .........Committee Testimony; Recording; Transcripts .................................Page 30

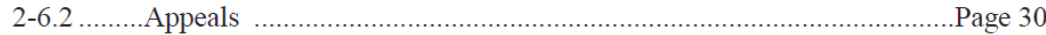

PART 7: COMMITTEE OF THE WHOLE

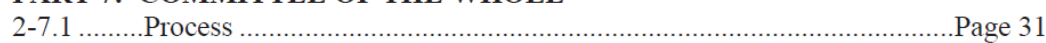

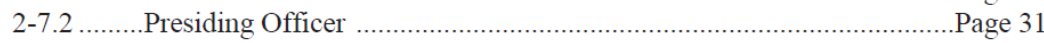

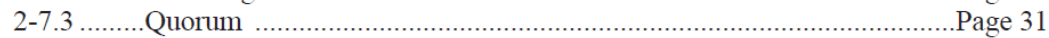

2-7.4 .........Reading of Bills; Order of Debate ....................................................... 31

2-7.5 .........Applicability of Senate Rules; Limitations; Powers ..........................Page 32

2-7.6 ......... Voting Responsibilities of Members ............................................ 32

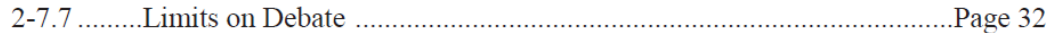

2-7.8 ...........Motion to Rise, Report Progress, and Ask Leave to Sit Again ..............Page 32

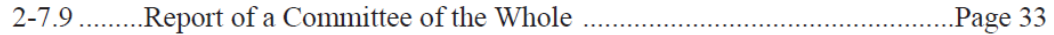

$2-7.10 \ldots \ldots$. Amendments by a Committee of the Whole ........................................Page 33

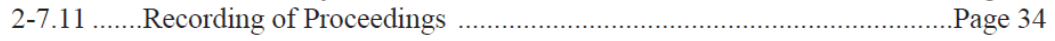

PART 8: COMMITTEE OF CONFERENCE

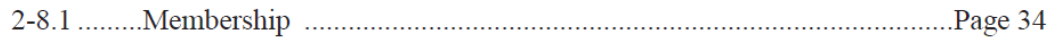

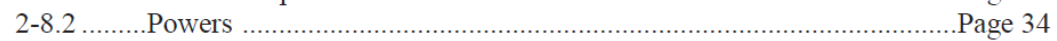

2-8.3 ........Reports; Approval; Distribution; Time of Consideration ..................Page 34

2-8.4 .........Time Limit; Discharge; Appointment of New Members ....................Page 35

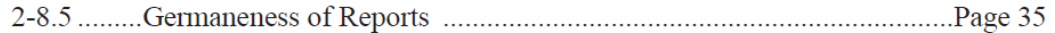

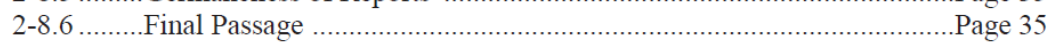

\section{SECTION THREE}

\section{BILLS, RESOLUTIONS, AND CONFIRMATIONS}

PART 1: GENERAL BILLS AND RESOLUTIONS

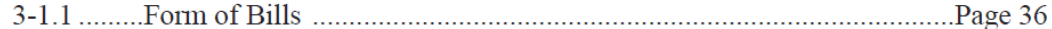

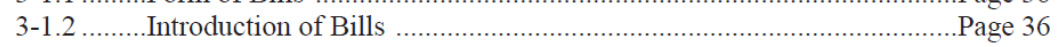

3-1.3 ........Distribution of Bills; Printing Amendments ..................................Page 37

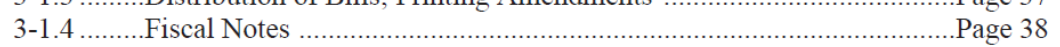

3-1.5 ........Receipt of House Bills on the Crossover Day ..................................... 39

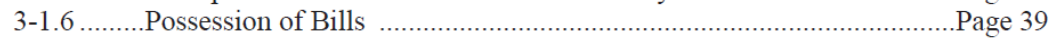

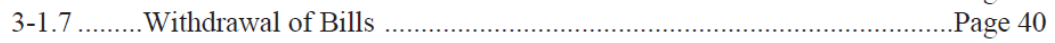

3-1.8 .........Failed Bills; Prohibition Against Reintroduction .............................Page 40 
PART 2: LOCAL BILLS

3-2.1 ..........ocal Bills; General Provisions ....................................................... 40

3-2.2 ........Approval by Local Delegation .....................................................Page 41

PART 3: CONFIRMATIONS

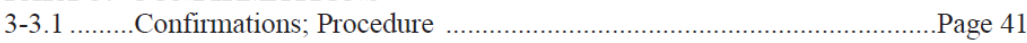

\section{SECTION FOUR}

\section{ORDER OF BUSINESS AND CALENDAR}

PART 1: CALENDAR AND SCHEDULE

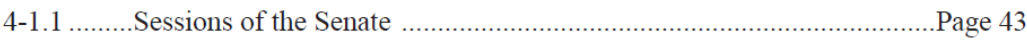

4-1.2 ........Adjournment of Both Houses .......................................................Page 43

PART 2: ORDER OF BUSINESS

4-2.1 ........Daily Order of Business .............................................................. 4 age 44

4-2.2 .........Reports of the Committees on Rules and State

And Local Governmental Operations (Local); Messages .....................Page 45

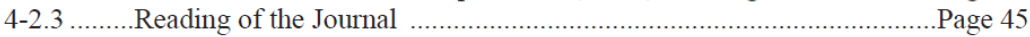

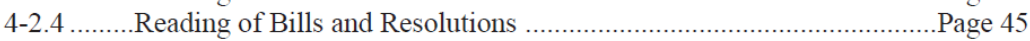

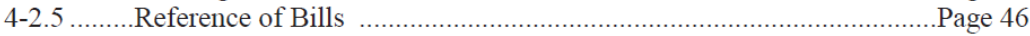

4-2.6 .......... Order for Second Reading; Second Reading after the 35th Day ..........Page 46

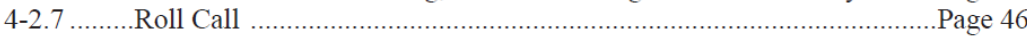

4-2.8 .......... Local Consent Calendar; Local Contested Calendar .........................Page 46

4-2.9 ….....Third Reading and Consideration; Rules Calendar ...........................Page 47

4-2.10 .......Bills Placed on Desk; Calendar Changes ........................................Page 48

4-2.11 .......Reference to More Than One Committee; Effect .................................. 48

4-2.12 .......Disagreement with Committee Report on Third Reading .................Page 48

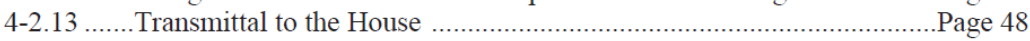

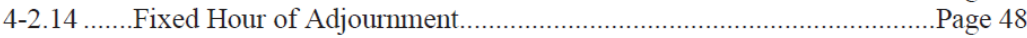




\section{SECTION FIVE}

\section{VOTING}

\begin{tabular}{|c|c|c|}
\hline $5-1.1$ & Votes Required for Passage & ..Page 49 \\
\hline $5-1.2$ & .Quorum & ..Page 49 \\
\hline $5-1.3$ & Voting; General & Page 50 \\
\hline $5-1.4$ & Final Passage . & ..Page 50 \\
\hline $5-1.5$ & Electronic Roll Call System & Page 51 \\
\hline $5-1.6$ & Debate Prohibited During Voting & ..Page 51 \\
\hline $5-1.7$ & Verification of Vote; Change of Vote .. & ..Page 51 \\
\hline $5-1.8$ & 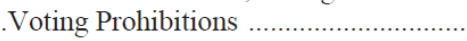 & ..Page 52 \\
\hline $5-1.9$ & Explanation of Vote & ..Page 52 \\
\hline 510 & $\begin{array}{l}\text { No Quorum Present; Call of the Senate } \\
\text { Members Required to Vote }\end{array}$ & ge 52 \\
\hline
\end{tabular}

\section{SECTION SIX}

\section{MOTIONS AND PRECEDENCE}

\section{PART 1: MOTIONS GENERALLY}

6-1.1 ..........Motions; How Made, Withdrawn ........................................................... 53

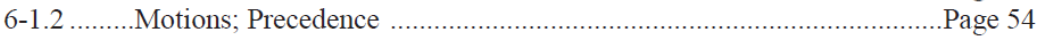

PART 2: MOTION TO ADJOURN

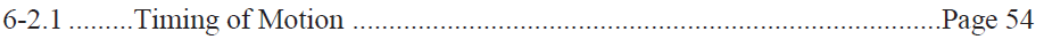

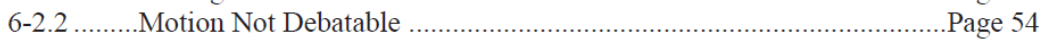

6-2.3 ..........Motion to Adjourn to a Particular Day ............................................ 55

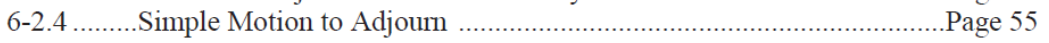

\section{PART 3: MOTION TO TABLE}

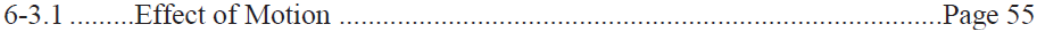

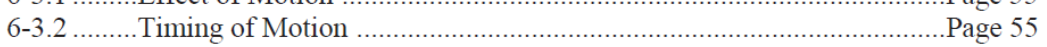

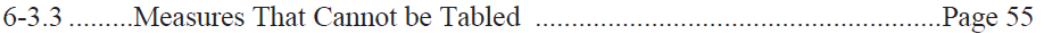

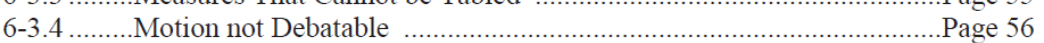

6-3.5 ….....Removing Measures From the Table ................................................. 56

PART 4: MOTION TO INDEFINITELY POSTPONE

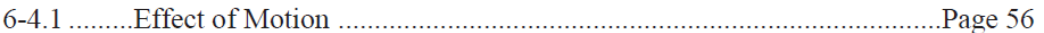

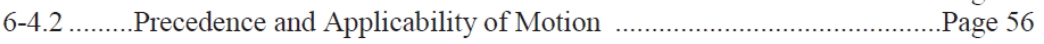

6-4.3 …........ 
PART 5: MOTION TO POSTPONE

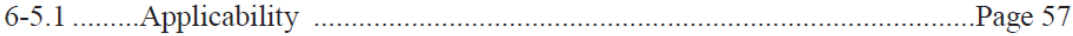

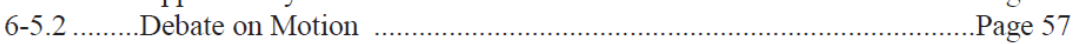

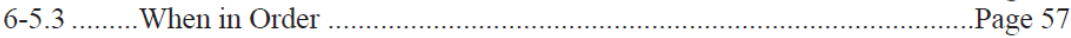

6-5.4 .........Effect of Motion; Return to General Calendar ....................................... 57

PART 6: MOTION TO COMMIT

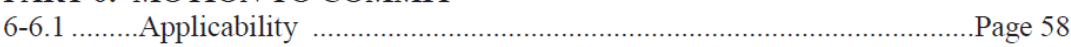

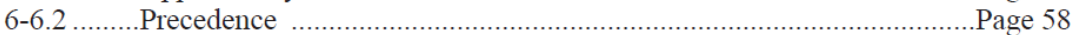

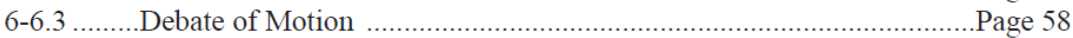

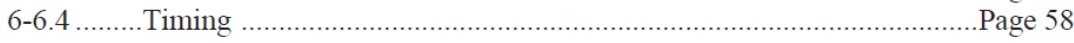

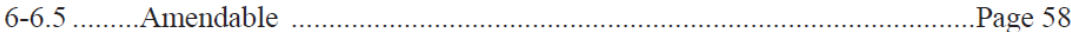

6-6.6 ......... Vote Required for Passage .......................................................... 59

PART 7: RECONSIDERATION

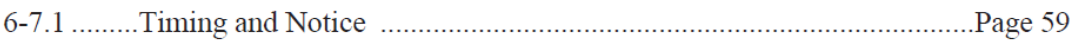

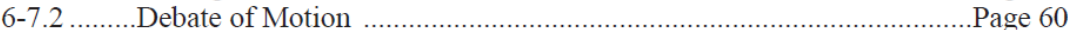

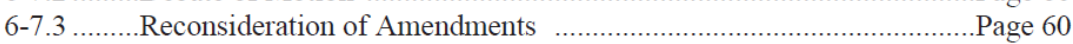

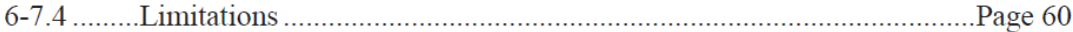

6-7.5 .........Effect of Motion; Return to General Calendar ...................................Page 60

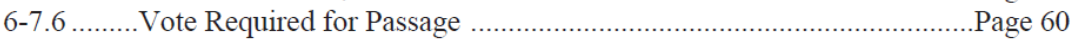

PART 8: MOTION FOR THE PREVIOUS QUESTION

6-8.1 …..... How Made; Precedence; Motion not Debatable ................................Page 60

$6-8.2$.........When Motion is Not in Order ............................................................ 61

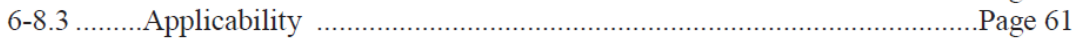

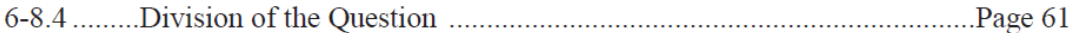

6-8.5 .........Effect; Time for Debate of Main Question; Minority Reports ..............Page 61

6-8.6 ......... Order of Business After Main Question is Ordered ...........................Page 62

6-8.7 .........Reconsideration After Main Question is Ordered ................................ 62

PART 9: OTHER MOTIONS

6-9.1 .........Motion to Engross Upon First Reading or Third Reading ..................Page 62

$6-9.2 \ldots \ldots . .$. Motions Containing New Matters ..................................................Page 63

6-9.3 ..........Motion to Resolve Debate .............................................................. 63 


\section{SECTION SEVEN}

\begin{tabular}{|c|c|}
\hline \multicolumn{2}{|l|}{ AMENDMENTS } \\
\hline 7-1.1 .........General Form; Notice; Manner of Consideration & ...Page 64 \\
\hline $7-1.2$ _.......Germaneness & ...Page 65 \\
\hline $7-1.3$............Timing ............. & ...Page 65 \\
\hline 7-1.4 ….....Precedence of Amendments & ...Page 65 \\
\hline $7-1.5$.........Amendments to Amendments . & ...Page 65 \\
\hline 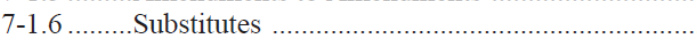 & ...Page 66 \\
\hline $7-1.7$.........Amendments to the Title of a Bill or Resolution & ...Page 66 \\
\hline $7-1.8 \ldots \ldots . .$. Amendment by Paragraph & ...Page 67 \\
\hline 7-1.9 .........Amendments to Appropriations Bills . & ...Page 67 \\
\hline 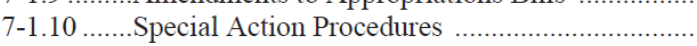 & ...Page 67 \\
\hline
\end{tabular}

\section{SECTION EIGHT}

\section{DEBATE}

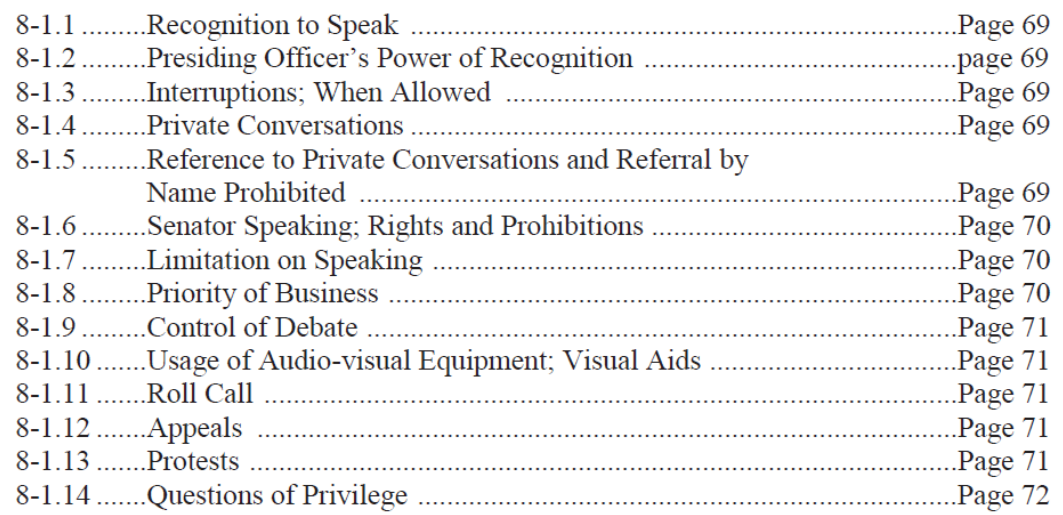




\section{SECTION NINE}

\section{DECORUM}

\begin{tabular}{|c|c|}
\hline & ..Senatorial Conduct \\
\hline-1.2 & ..Contempt; Disorderly Conduct \\
\hline 1 & ..Introductions and Addresses to the Senate \\
\hline 1. & ..Persons Entitled to Admissio \\
\hline 1.5 & ..Doorkeepers \\
\hline 1.6 & ..Secretaries, Inte \\
\hline & ..Appropriations \\
\hline 1.8 . & ..Pages \\
\hline-1.9 . & ..Media \\
\hline-1.10 & ..Spouses, Fam \\
\hline-1.11 & ..North Antero \\
\hline 1.12 & . Sen \\
\hline-1.13 & ...Smoking, Eating \\
\hline 1.14 & ..Use of Comput \\
\hline 1.15 & ..Etiquette in the Chamber \\
\hline-1.16 & ..Gallery and Senate Environs \\
\hline
\end{tabular}

\section{SECTION TEN}

\section{CONSTRUCTION AND WAIVER OF THE RULES}

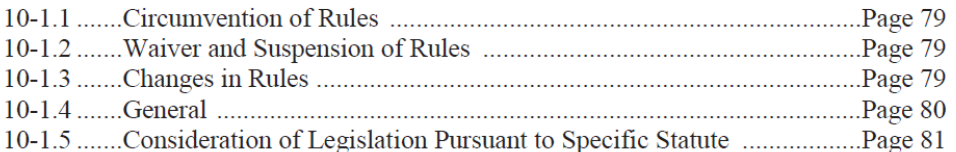

Source: Georgia State Senate website link http://www.senate.ga.gov/sos/Documents/2019SenateRules.pdf 


\section{Exhibit 8: Cornerstone Communications Group}

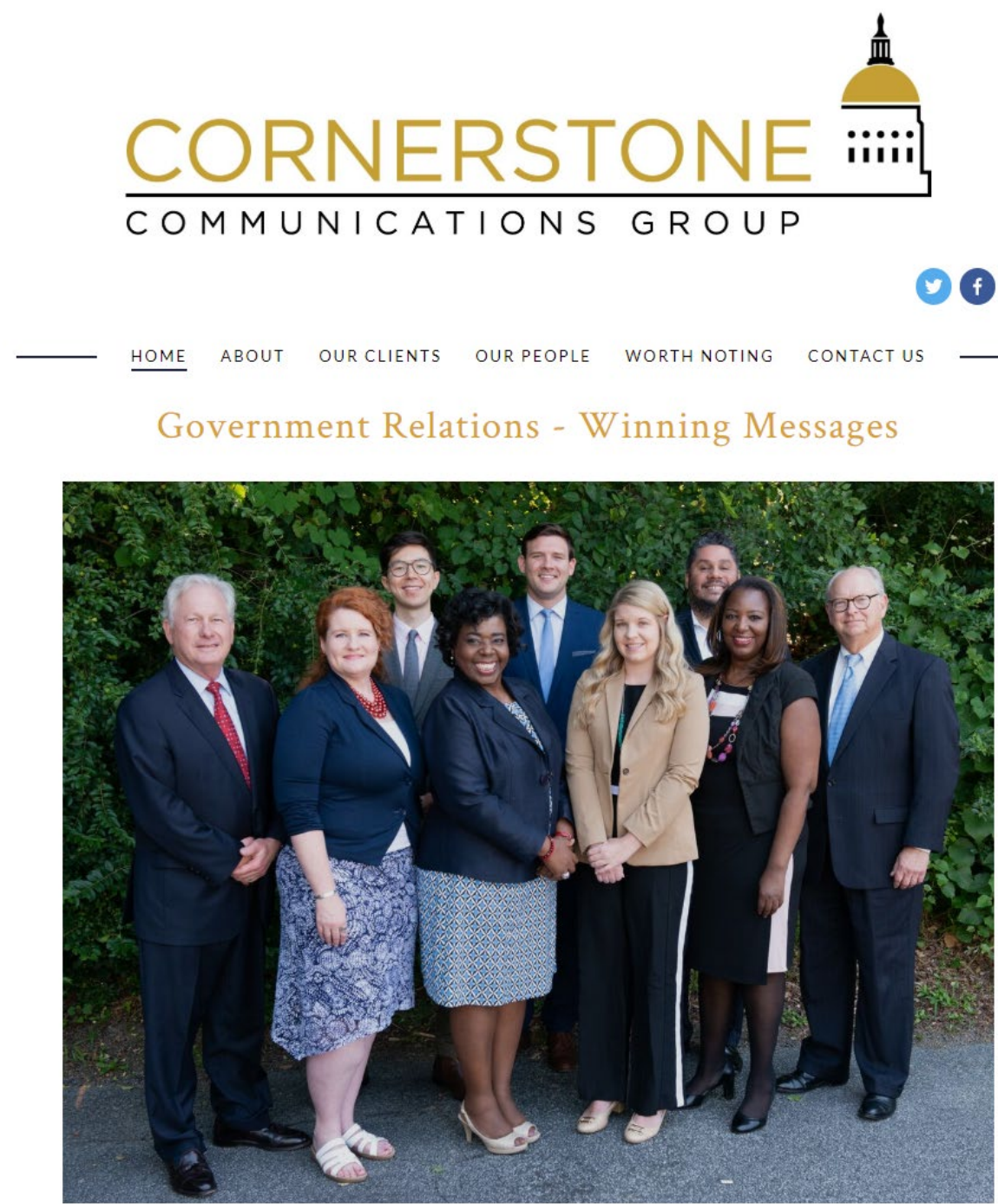

Association Management - Crisis Communications

Source: Cornerstone Communications Group website tab Our People http://www.cstone1.com/new-page 


\section{Exhibit 9: GICA Member Institutions}

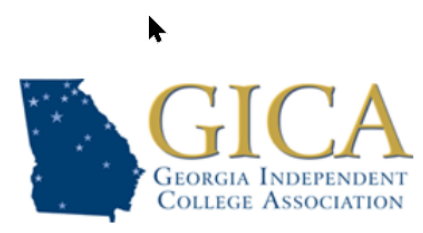

Private Colleges, Public Good

ABOUT 、 ADVOCATE \& RESEARCH 、 COLLABORATE 、 LEARN\& NETWORK PARTNER

\section{Member Institutions}

About " Member Institutions

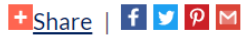

GICA counts among its members 24 four-year institutions across the state. These institutions serve over 70,000 students.

\section{Agnes Scott College}

Andrew College

Berry College

Brenau University.

Brewton-Parker College

Clark Atlanta University.

Covenant College

Emmanuel College

Emory University.

LaGrange College

Life University.

Mercer University.

Morehouse College

Oglethorpe University.

Piedmont College

Point University.

Reinhardt University.

Shorter University.

Spelman College

Thomas University

Toccoa Falls College

Truett McConnell University.

Wesleyan College

Young Harris College

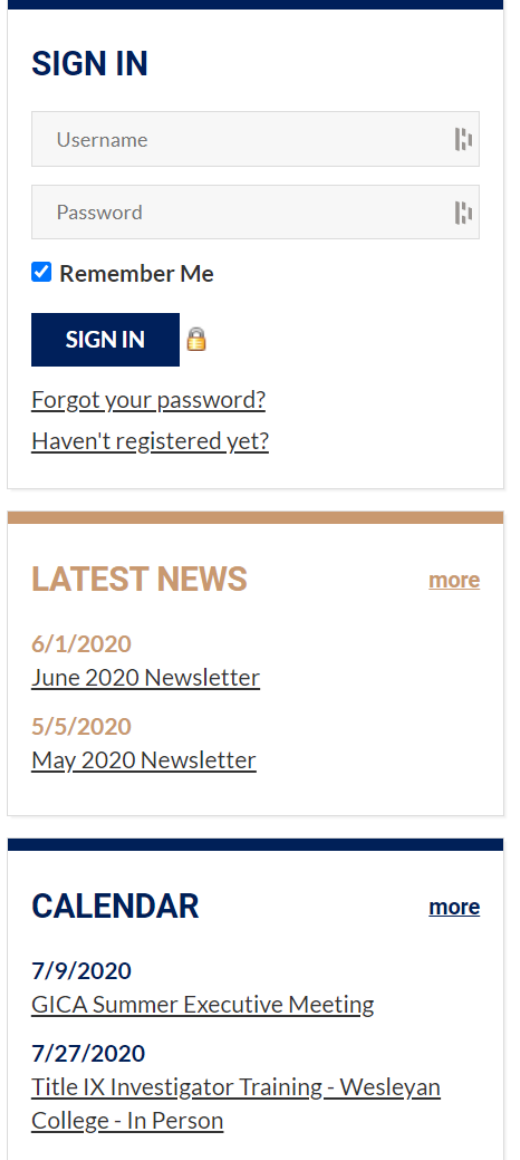

\section{Corporate Allies Partner

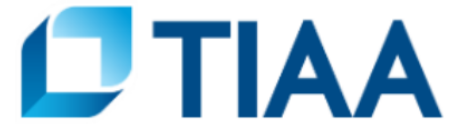

Source: GICA website https://georgiacolleges.org/page/MemberInstitutions. 


\section{Exhibit 10: GICA Annual Report 2018}

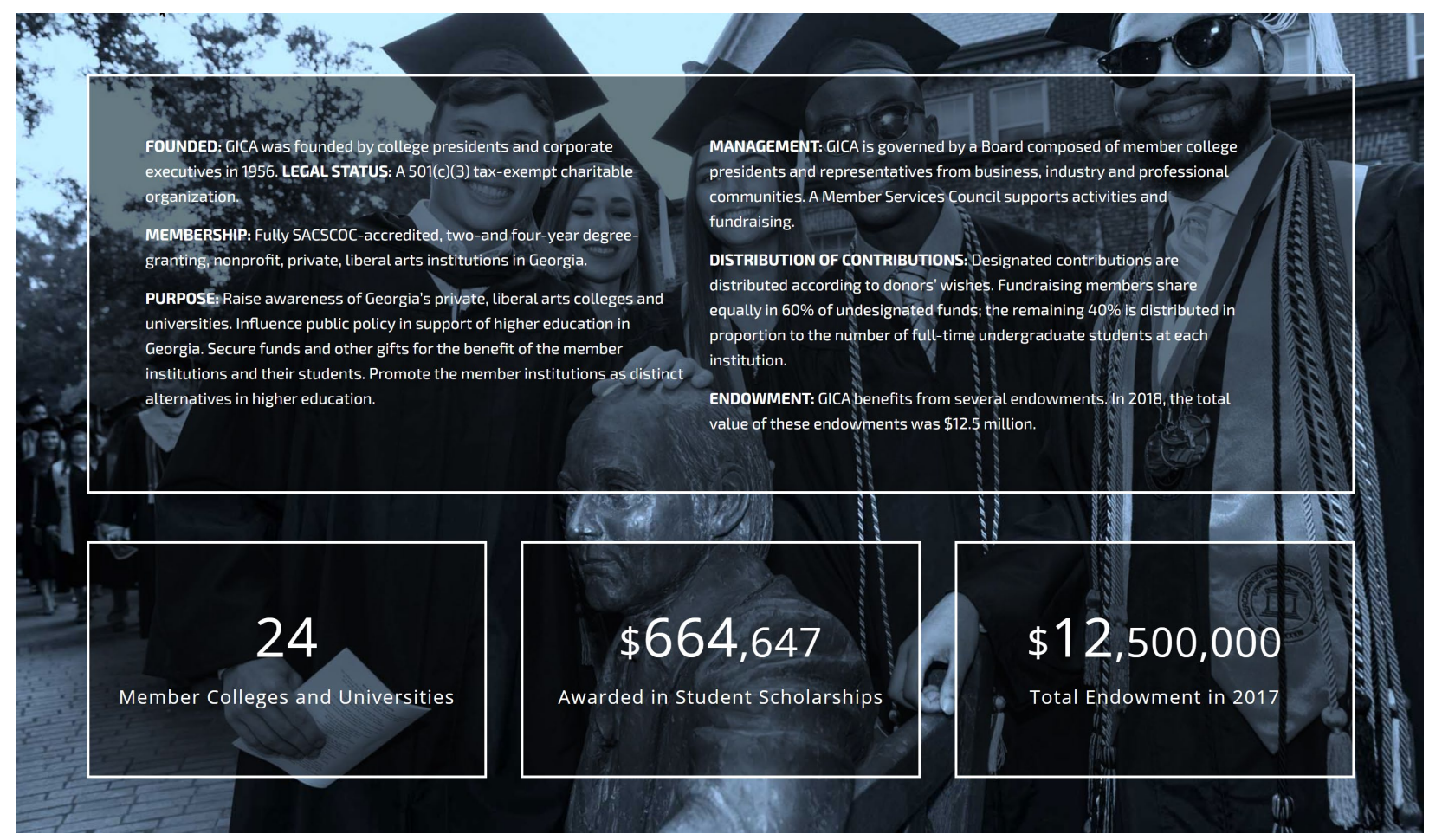

Source: GICA website http://www.ar-gica.org/2018. 


\title{
Exhibit 11: State Tuition Equalization Grant Eligible Institutions
}

\author{
Tuition Equalization Grant Eligible Institutions $\quad$ Effective FY 2021
}

\begin{tabular}{|l|}
\hline \multicolumn{1}{|c|}{ PRIVATE } \\
\hline Agnes Scott College \\
American InterContinental University \\
Andrew College \\
Art Institute of Atlanta \\
Berry College \\
Brenau University \\
Brewton-Parker College \\
Clark Atlanta University \\
Covenant College \\
DeVry University \\
Embry-Riddle Aeronautical University \\
Emmanuel College \\
Emory University \\
Georgia Military College \\
Herzing University \\
LaGrange College \\
Life University \\
Mercer University \\
Morehouse College \\
Oglethorpe University \\
Paine College \\
Piedmont College \\
Point University \\
Reinhardt University \\
Saint Leo University \\
Savannah College of Art \& Design \\
Shorter University \\
South University \\
Spelman College \\
Thomas University \\
Toccoa Falls College \\
Truett McConnell University \\
Wesleyan College \\
Young Harris College \\
\\
\end{tabular}

\section{GSFC| $\mid \begin{aligned} & \text { Georgia Student } \\ & \text { Finance Commission }\end{aligned}$}

Source: Georgia Student Finance Commission website https://www.gafutures.org/media/188147/covidhigh-school-hope-gpa-cal-faqs-4-8-2020.pdf 